\title{
High Molecular Weight Forms of Mammalian Respiratory Chain Complex II
}

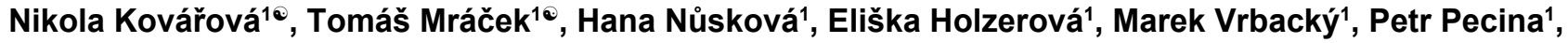 \\ Kateřina Hejzlarová1, Katarína Kl’učková2 ${ }^{2}$, Jakub Rohlena ${ }^{2}$, Jiri Neuzili ${ }^{2,3}$, Josef Houštěk ${ }^{1 *}$
}

1 Department of Bioenergetics, Institute of Physiology Academy of Sciences of the Czech Republic, Prague, Czech Republic, 2 Laboratory of Molecular Therapy, Institute of Biotechnology Academy of Sciences of the Czech Republic, Prague, Czech Republic, 3 Apoptosis Research Group, School of Medical Science and Griffith Health Institute, Griffith University, Southport, Queensland, Australia

\begin{abstract}
Mitochondrial respiratory chain is organised into supramolecular structures that can be preserved in mild detergent solubilisates and resolved by native electrophoretic systems. Supercomplexes of respiratory complexes I, III and IV as well as multimeric forms of ATP synthase are well established. However, the involvement of complex II, linking respiratory chain with tricarboxylic acid cycle, in mitochondrial supercomplexes is questionable. Here we show that digitonin-solubilised complex II quantitatively forms high molecular weight structures $\left(\mathrm{CII}_{\mathrm{hmw}}\right)$ that can be resolved by clear native electrophoresis. $\mathrm{ClI}_{\mathrm{hmw}}$ structures are enzymatically active and differ in electrophoretic mobility between tissues (500 - over $1000 \mathrm{kDa}$ ) and cultured cells (400-670 kDa). While their formation is unaffected by isolated defects in other respiratory chain complexes, they are destabilised in mtDNA-depleted, rho0 cells. Molecular interactions responsible for the assembly of $\mathrm{ClI}_{\mathrm{hmw}}$ are rather weak with the complexes being more stable in tissues than in cultured cells. While electrophoretic studies and immunoprecipitation experiments of $\mathrm{CI}_{\mathrm{hmw}}$ do not indicate specific interactions with the respiratory chain complexes I, III or IV or enzymes of the tricarboxylic acid cycle, they point out to a specific interaction between CII and ATP synthase.
\end{abstract}

Citation: Kovářová N, Mráček T, Nůsková H, Holzerová E, Vrbacký M, et al. (2013) High Molecular Weight Forms of Mammalian Respiratory Chain Complex II. PLoS ONE 8(8): e71869. doi:10.1371/journal.pone.0071869

Editor: Nagendra Yadava, UMASS-Amherst/Tufts University School of Medicine, United States of America

Received May 14, 2013; Accepted July 10, 2013; Published August 13, 2013

Copyright: @ 2013 Kovářová et al. This is an open-access article distributed under the terms of the Creative Commons Attribution License, which permits unrestricted use, distribution, and reproduction in any medium, provided the original author and source are credited.

Funding: This work was supported by the Grant Agency of the Czech Republic (P303/10/P227, P301/10/1937), Ministry of Education, Youth and Sports of the Czech Republic (ERC CZ LL1204 and RVO: 67985823) and Ministry of Health of the Czech Republic (NT12370-5). The funders had no role in study design, data collection and analysis, decision to publish, or preparation of the manuscript.

Competing interests: The authors have declared that no competing interests exist.

*E-mail: houstek@biomed.cas.cz

๑ These authors contributed equally to this work.

\section{Introduction}

The mitochondrial oxidative phosphorylation system (OXPHOS) is the main source of energy in mammals. This metabolic pathway is localised in the inner mitochondrial membrane (IMM) and includes the respiratory chain complexes I, II, III and IV (CI, CII, CIII, CIV), ATP synthase (complex V, $\mathrm{CV}$ ), plus the mobile electron transporters coenzyme $\mathrm{Q}(\mathrm{CoQ})$ and cytochrome $c$. Energy released by oxidation of NADH and $\mathrm{FADH}_{2}$ is utilised for proton transport across the membrane to establish proton gradient. The resulting electrochemical potential $\left(\Delta \mu_{H}{ }^{+}\right)$is then utilised as a driving force for phosphorylation of ADP by ATP synthase.

CII (succinate: ubiquinone oxidoreductase; EC 1.3.5.1), catalyses electron transfer from succinate $\left(\right.$ via $F A D H_{2}$ ) to $\mathrm{CoQ}$ and thus represents important crossroads of cellular metabolism, interconnecting the tricarboxylic acid (TCA) cycle and the respiratory chain [1]. It consists of 4 nuclear encoded subunits. The hydrophilic head of $\mathrm{Cll}$ is formed by the SDHA subunit with covalently bound FAD and the SDHB subunit, which contains three Fe-S centres. The SDHC and SDHD subunits form the hydrophobic membrane anchor and are the site of cytochrome $b$ binding [2].

Mutations in genes coding for any of the Cll subunits are associated with severe neuroendocrine tumours such as paraganglioma and phaeochromocytoma [3-5] as well as other tumour types, including gastrointestinal stromal tumours [6] or renal tumours [7]. Conversely, the Cll subunits also function as tumour suppressors and represent one of the potential molecular targets of anti-cancer drugs [8], whose mechanisms of action could lead to apoptosis of cancer cells through the inhibition of Cll and a consequent metabolic collapse.

In comparison with other respiratory chain complexes, the assembly of $\mathrm{Cll}$ has not yet been fully characterised. Up to now, two evolutionarily conserved assembly factors for CII have been described; SDHAF1 was discovered as disease- 
causing gene in a case of infantile leukoencephalopathy presenting with a decrease in the CII content and activity [9]. The LYR motif in the protein structure suggests its role in the metabolism of the Fe-S centres [10]. The second assembly factor, SDH5, is a soluble mitochondrial matrix protein, which is most likely required for insertion of FAD into the SDHA subunit [11].

Recent studies indicate that the organisation of the OXPHOS complexes in the inner mitochondrial membrane (IMM) is characterised by non-stochastic protein-protein interactions. Individual complexes specifically interact with each other to create supramolecular structures referred to as supercomplexes (SCs). SCs behave as individual functional units, enabling substrate channelling [12]; more effective electron transport should prevent electron leak and reactive oxygen species generation [13]. Besides the kinetic advantage, SCs stabilise OXPHOS complexes and help to establish the IMM ultrastructure [14].

To date, the presence of CII in SCs is still a matter of debate. In yeast and mammalian mitochondria, the interaction of $\mathrm{Cl}$, III, IV and $\mathrm{V}$ within different types of SCs has been proven using native electrophoretic techniques in combination with mild detergents and/or the Coomassie Blue G (CBG) dye $[15,16]$. However, the presence of $\mathrm{Cll}$ in such structures has only been reported by Acín-Peréz et al. [17], who described the existence of a large respirasome comprising all OXPHOS complexes including $\mathrm{Cll}$ in mammalian cells. On the other hand, CII has been detected as a structural component of the mitochondrial ATP-sensitive $\mathrm{K}^{+}$channel $\left(\right.$mitoK $_{\text {ATP }}$ ) [18]. Such structures do indeed represent higher molecular forms of CII, but their structural and physiological importance remains to be investigated.

CII as the only membrane bound component of the TCA cycle could also form complexes with other TCA cycle proteins, e.g. with its functional neighbours fumarase and succinyl CoA lyase. Different studies indicate the existence of a TCA cycle metabolon and possible supramolecular organisation of various parts of the TCA cycle $[19,20]$, but these may be significantly more labile than the well described respiratory chain SCs.

In the present study we demonstrate the existence of high molecular weight forms of $\mathrm{Cll}\left(\mathrm{Cll}_{\mathrm{hmw}}\right)$, i.e. SCs containing Cll, using mitochondrial membrane solubilisation with mild nonionic detergents followed by electrophoretic analysis. These complexes are rather labile, and the presence of $n$-dodecyl- $\beta$ $D$-maltoside or CBG during the electrophoretic separation causes their dissociation to individual units. $\mathrm{ClI}_{\mathrm{hmw}}$ structures differ in their electrophoretic migration between mammalian cells and tissues, and their formation depends on the presence of the functional respiratory chain. Our experiments also clearly indicate the association of $\mathrm{Cll}$ with $\mathrm{CV}$.

\section{Materials and Methods}

\section{Cell lines}

The following cell lines were used in experiments: control human fibroblasts and fibroblasts from patients with isolated deficiency of $\mathrm{Cl}$ (an unknown mutation), CIV (the SURF1 mutation, described in $[21,22]$ ), CV (the TMEM70 mutation described in [23]), human rho0 $\left(\rho^{0}\right)$ cells (mtDNA-depleted 143B TK- osteosarcoma cells [24]), human embryonic kidney cells HEK293, primary mouse (derived from the C57/BI6 strain) and rat (derived from the SHR strain) fibroblasts. All cell lines were grown in the high-glucose DMEM medium (Lonza) supplemented with $10 \%(\mathrm{v} / \mathrm{v})$ foetal bovine serum (Sigma) at $37{ }^{\circ} \mathrm{C}$ in $5 \% \mathrm{CO}_{2}$ atmosphere. Cells were harvested using $0.05 \%$ trypsin and $0.02 \%$ EDTA and stored as pellets at $-80{ }^{\circ} \mathrm{C}$.

\section{Isolation of cell membranes and mitochondria from cells and tissues}

Mitochondria from cultured cells were isolated after cell disruption by hypotonic shock as described [25]. In some experiments, membrane fractions from fibroblasts were prepared as described [26]. Human heart mitochondria and mitochondria from rat heart, liver and brown adipose tissues were isolated according to established procedures [27]. The protein concentration was measured by the Bradford method (BioRad).

\section{Ethical aspects}

All work involving human samples was carried out in accordance with the Declaration of Helsinki of the World Medical Association and was approved by the Ethics Committee of the Institute of Physiology, Academy of Sciences of the Czech Republic v.v.i. The written informed consent was obtained from patients or patients' parents.

All animal tissues were obtained on the basis of approval by the Expert Committee for Work with Animals of the Institute of Physiology, Academy of Sciences of the Czech Republic v.v.i. (Permit Number: 165/2010) and animal work was in accordance with the EU Directive 2010/63/EU for animal experiments.

\section{Electrophoresis and western blot analysis}

Isolated membranes or mitochondria were solubilised with digitonin (Sigma, $4 \mathrm{~g} / \mathrm{g}$ protein) in an imidazole buffer $(2 \mathrm{mM}$ aminohexanoic acid, $1 \mathrm{mM}$ EDTA, $50 \mathrm{mM} \mathrm{NaCl}, 50 \mathrm{mM}$ imidazole, $\mathrm{pH} 7.0$ ) for $15 \mathrm{~min}$ at $0{ }^{\circ} \mathrm{C}$ and centrifuged for $20 \mathrm{~min}$ at $20000 \mathrm{~g}$ [26]. Samples were prepared by adding 5\% (v/v) glycerol and $0.005 \%(\mathrm{v} / \mathrm{v})$ Ponceau $\mathrm{S}$ dye for clear native and high resolution clear native electrophoresis (CNE, hrCNE3), or $5 \%(\mathrm{v} / \mathrm{v}$ ) glycerol and CBG dye (Serva Blue G 250, 1:8 ratio $(\mathrm{w} / \mathrm{w})$ to digitonin) for blue native electrophoresis (BNE). Separation of mitochondrial proteins was performed using CNE, BNE [26] and hrCNE3 [28] on 6-15\% polyacrylamide gradient gels using the Mini-Protean apparatus (BioRad). For 2D separation by CNE/SDS PAGE, the gel after CNE was cut into stripes that were incubated in $1 \%$ SDS and 1\% 2mercaptoethanol for $1 \mathrm{~h}$ and then subjected to SDS PAGE on a $10 \%$ slab gel [29]. In case of $2 \mathrm{D}$ separation by $\mathrm{CNE} / \mathrm{CNE}_{\mathrm{CBG}}$, gel stripes after CNE were incubated in $3 \%$ CBG in the CNE cathode buffer for $1 \mathrm{~h}$ and then subjected to CNE on $6-15 \%$ gradient gels.

For western blot immunodetection, the separated proteins were transferred to a PVDF membrane (Immobilon-P, Millipore) by semi-dry electrotransfer. The membranes were blocked with $5 \%(\mathrm{w} / \mathrm{v})$ non-fat dried milk in TBS (150 mM NaCl, $10 \mathrm{mM}$ Tris, 
$\mathrm{pH}$ 7.5) for $1 \mathrm{~h}$ and incubated overnight at $4{ }^{\circ} \mathrm{C}$ with specific primary antibodies diluted in TBST (TBS with $0.1 \%$ Tween-20). Monoclonal or polyclonal primary antibodies to the following enzymes of OXPHOS or TCA cycle were used: SDHA (ab14715, Abcam), SDHB (ab14714, Abcam), Core1 (ab110252, Abcam), NDUFA9 (ab14713, Abcam), Cox4 (ab14744, ab110261, Abcam), citrate synthase (ab129095, Abcam), isocitrate dehydrogenase ( $\alpha$ subunit, ab58641, Abcam), aconitase 2 (ab110321, Abcam), a subunit of CV [30], fumarase (M01, Abnova), succinyl-CoA synthetase (a subunit, 5557, Cell Signaling Technology) and malate dehydrogenase (8610, Cell Signaling Technology). The detection of the signals was performed with the secondary Alexa Fluor 680-labelled antibody (Life Technologies) using the Odyssey fluorescence scanner (LI-COR).

\section{Enzyme in-gel activity staining}

In-gel activity assays were performed after separation of the respiratory complexes using CNE. For CIV in-gel activity staining, we used a recently described protocol [21]. The in-gel activity assay of the CV ATP hydrolytic activity was performed as described [28]. The activity of CII was detected using the modified succinate: nitroblue tetrazolium reductase assay [28]. Briefly, gel slices from CNE were incubated for $1 \mathrm{~h}$ (for tissues) or overnight (for cells) at room temperature in the dark in the staining solution (200 mM Tris, $\mathrm{pH}$ 7.4), $10 \mathrm{mM}$ EDTA, 1 $\mathrm{mg} / \mathrm{mL}$ nitroblue tetrazolium, $80 \mu \mathrm{M}$ phenazine methosulfate, 2 $\mathrm{mM} \mathrm{KCN}, 1.5 \mu \mathrm{g} / \mathrm{mL}$ rotenone and $30 \mathrm{mM}$ succinate).

\section{Immunoprecipitation}

For co-immunoprecipitation analysis we used a rabbit polyclonal antibody against the $F_{1}$ part of ATP synthase (reacting with the ATP synthase subunits $\alpha, \gamma$, and predominantly $\beta$, generated in our laboratory) or a mouse monoclonal antibody against the SDHA subunit of CII (ab14715, Abcam). The antibodies were immobilised on $\mathrm{CNBr}$ activated agarose matrix (Sigma). Agarose beads with the bound antibody were equilibrated in PBS (140 mM NaCl, $5 \mathrm{mM}$ $\mathrm{KCl}, 8 \mathrm{mM} \mathrm{Na} \mathrm{HPO}_{4}, 1.5 \mathrm{mM} \mathrm{KH}{ }_{2} \mathrm{PO}_{4}, \mathrm{pH} 7.2$-7.3) supplemented with $0.2 \%$ protease inhibitor cocktail (PIC, Sigma). For storage at $4{ }^{\circ} \mathrm{C}$, they were dissolved in PBS+PIC supplemented with $0.025 \%$ thimerosal (Sigma). Solubilisation of rat heart mitochondria and human fibroblasts was performed with digitonin (2 $\mathrm{g} / \mathrm{g}$ protein) in PBS+PIC. The solubilisates were mixed with the antibody-conjugated agarose beads and diluted with PBS+PIC supplemented with the same digitonin concentration as for sample solubilisation. The mixture was incubated overnight at $4{ }^{\circ} \mathrm{C}$ on a rotating mixer. The beads were then washed three times with PBS+PIC+digitonin (the same concentration as for sample solubilisation), PBS+PIC + digitonin (ten times diluted), and finally with PBS+PIC. All the washing steps included incubation for $5 \mathrm{~min}$ at $4{ }^{\circ} \mathrm{C}$ on a rotating mixer and centrifugation at $1000 \mathrm{~g}$ for $1 \mathrm{~min}$ at room temperature. The pelleted beads were combined with a small volume of the 2x SDS sample lysis buffer and incubated at 65 ${ }^{\circ} \mathrm{C}$ for $15 \mathrm{~min}$. After a brief centrifugation, the supernatant with the released co-immunoprecipitated proteins was subjected to
SDS PAGE and western blot analysis using specific antibodies (described in section 2.4.).

\section{Results}

\section{High molecular weight forms of CII}

The mammalian Cll consists of four subunits, SDHA, SDHB, SDHC and SDHD, with the approximate molecular weight (MW) of $70,30,18$ and $17 \mathrm{kDa}$, respectively. Digitoninsolubilised $\mathrm{CII}$ from mitochondria of human fibroblasts was resolved by BNE (in the presence of $\mathrm{CBG}$ ) or hrCNE3 (in the presence of $n$-dodecyl- $\beta$-D-maltoside and deoxycholic acid in the cathode buffer) as a CII monomer of the expected mass of approximately $140 \mathrm{kDa}$ (Figure 1A, B) which represented most of the Cll signal. In addition, weaker bands smaller than 140 $\mathrm{kDa}$ and at approximately $200 \mathrm{kDa}$ were also present; these could be Cll sub-complexes and Cll hetero-oligomers. When milder conditions of separation were applied using CNE, a completely different pattern of the CII signal was obtained, indicating the presence of its higher molecular weight forms $\left(\mathrm{Cll}_{\mathrm{hmw}}\right)$. As revealed by immunodetection with the SDHA antibody, the signal of CII was almost completely localised within the region of $400-670 \mathrm{kDa}$ (Figure 1A). Similarly, the SDHB antibody (Figure 1B) or in-gel staining of $\mathrm{Cll}$ (SDH) activity (Figure 1C) confirmed the presence of CII in the 400$670 \mathrm{kDa}$ region. This was further demonstrated by 2D CNE/SDS PAGE analysis of the cells (Figure 2A), where the distributions of SDHA and SDHB in the second dimension gel indicate that the $\mathrm{Cl}_{\mathrm{hmw}}$ forms represent a complete and active CII, in accord with the profiles of Cll activity in CNE. For comparison, we also analysed the CIl profile in mitochondria isolated from rat heart and obtained similar results, except for the size of tissue $\mathrm{ClI}_{\text {hmw }}$ on CNE gels, which increased to $500-$ over $1000 \mathrm{kDa}$ when detected either with the SDHA or SDHB antibodies (Figure 1D, E) or by the in-gel SDH activity staining (Figure $1 \mathrm{~F}$ ). This was also confirmed by $2 \mathrm{D}$ analysis (Figure 2B).

Further, we analysed the distribution profiles of other OXPHOS complexes on 2D blots with subunit-specific antibodies in an attempt to determine potential Cll interaction partners within $\mathrm{ClI}_{\mathrm{hmw}}$. As expected, a substantially different migration pattern was found in the case of $\mathrm{Cl}$ (NDUFA9) while some CIII (Core1) signal overlapped with CII in heart, but not in fibroblasts (Figure 2A, B). The signal of CIV (Cox4) partially overlapped with that of $\mathrm{CII}_{\mathrm{hmw}}(\mathrm{SDHA}, \mathrm{SDHB})$, as shown by the distribution profiles below the western blot images. A similar overlap with the $\mathrm{ClI}_{\mathrm{hmw}}$ signal was found for $\mathrm{CV}$ (the a subunit), in particular in the case of fibroblasts (Figure 2A). This may reflect a coincidental co-migration of respective complexes because of the imprecise electrophoretic mobility inherent to the CNE system in the first dimension [31], but it can also indicate a possibility that $\mathrm{CII}_{\mathrm{hmw}}$ include SCs of CII with CIII, CIV or CV.

\section{$\mathrm{CII}_{\text {hmw }}$ differ between tissues and cells}

When CNE analysis of digitonin-solubilised proteins was performed using fibroblasts and different immortalised/ malignant human or rodent cell lines (Figure 3A), an analogous 


\section{Fibroblasts}

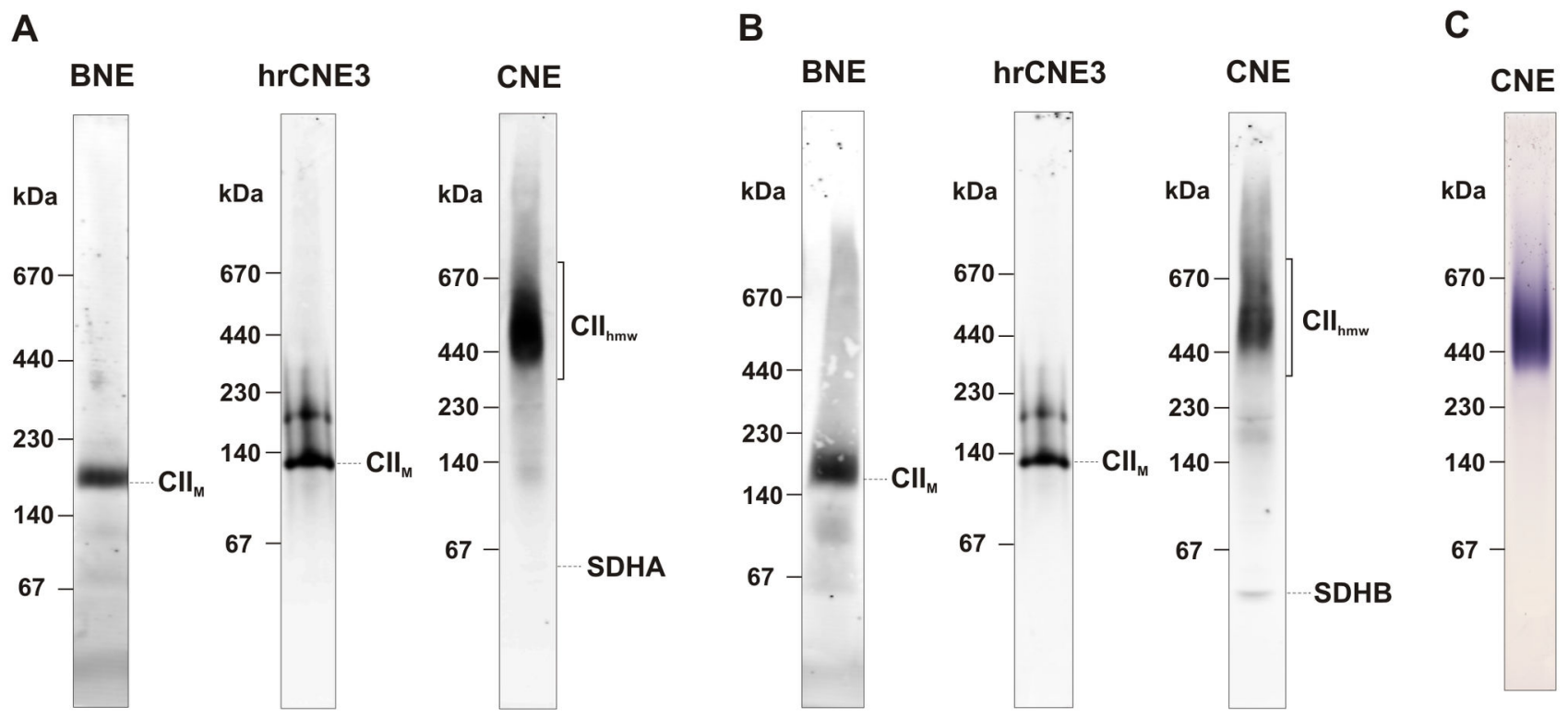

\section{Rat Heart}

D

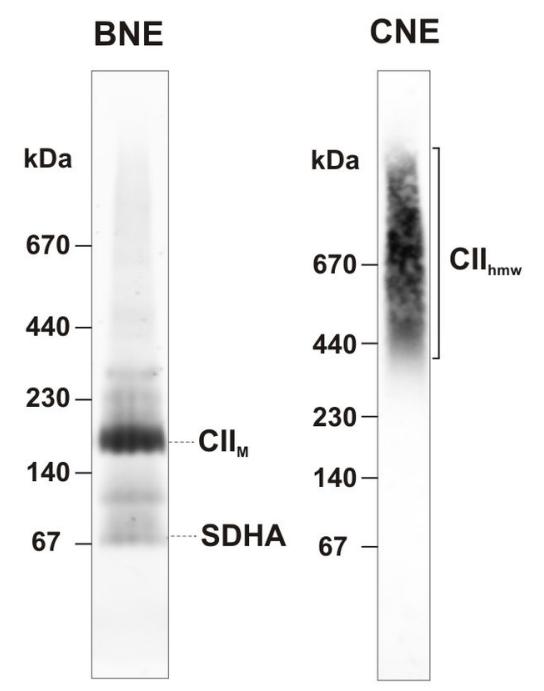

E

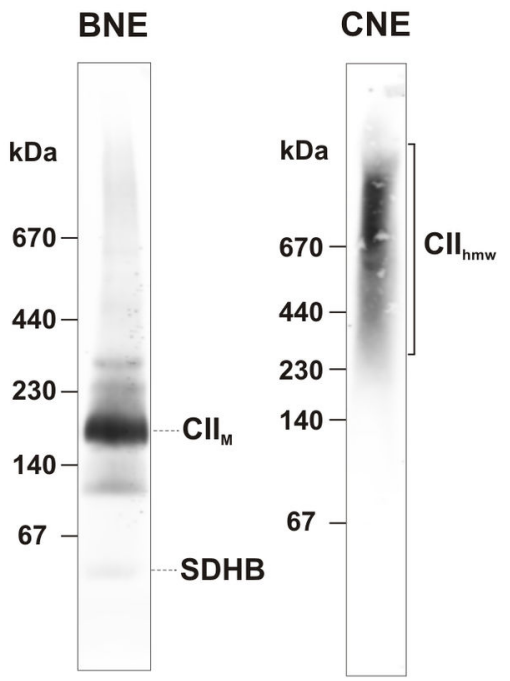

$\mathbf{F}$

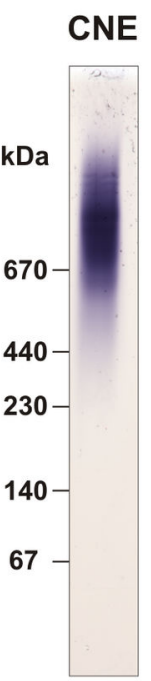

Figure 1. Higher molecular weight forms of complex II. Mitochondrial membrane proteins from control fibroblasts and rat heart were solubilised with digitonin $(4 \mathrm{~g} / \mathrm{g}$ protein), and $20 \mu \mathrm{g}$ protein aliquots were separated using BNE, hrCNE3 and CNE. CII was immunodetected with the SDHA antibody (A, D) and SDHB antibody (B, E). In-gel activity staining of CII was performed in CNE gels $(\mathrm{C}, \mathrm{F})$. Migrations of higher molecular weight forms of $\mathrm{Cll}\left(\mathrm{Cll}_{\mathrm{hmw}}\right)$, Cll monomer $\left(\mathrm{ClI}_{\mathrm{M}}\right)$, SDHA and SDHB subunits of Cll are marked. The images are representative of three independent experiments.

doi: 10.1371/journal.pone.0071869.g001

$\mathrm{ClI}_{\mathrm{hmw}}$ pattern was obtained in all human, mouse and rat cells, indicating that most of $\mathrm{Cll}$ is present as $\mathrm{ClI}_{\mathrm{hmw}}$. Similarly, $\mathrm{Cl}_{\mathrm{hmw}}$ was found as a predominant form of $\mathrm{Cll}$ in mitochondria of different human and rodent tissues (Figure 3B), suggesting that 
Fibroblasts

A
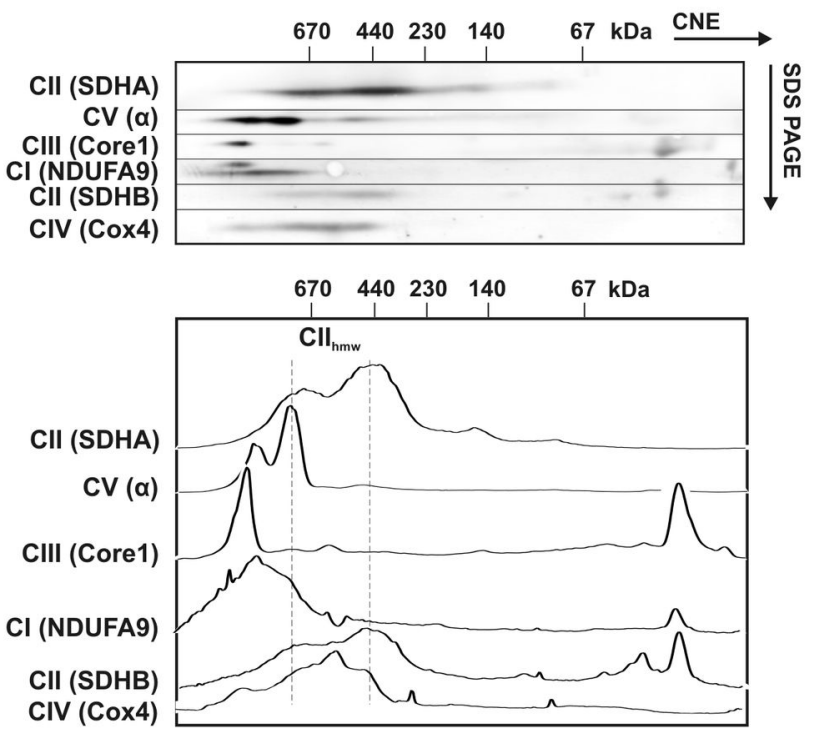

Rat Heart

B

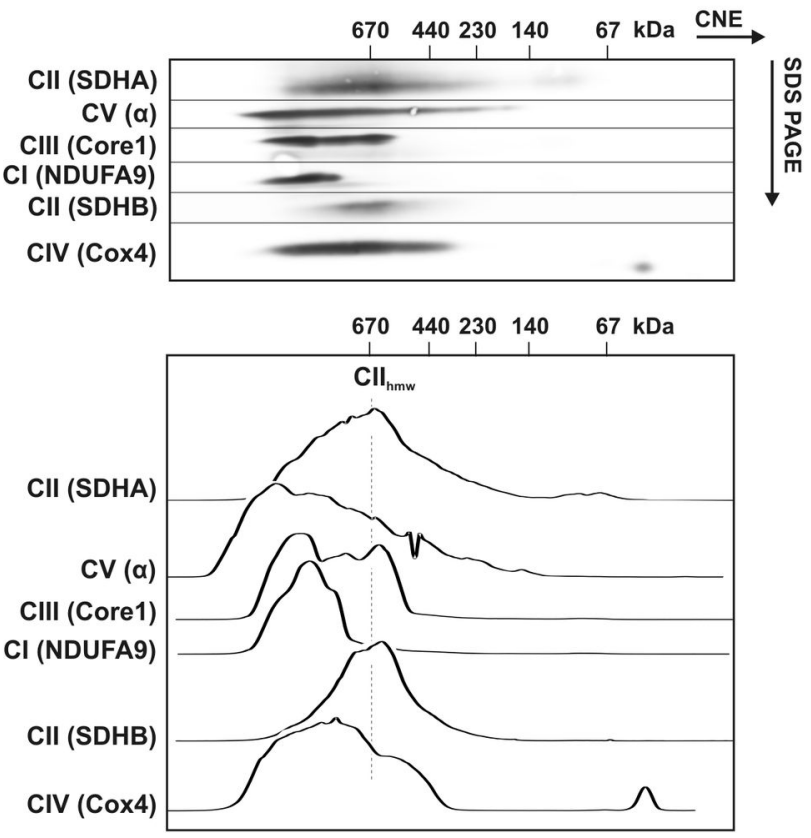

Figure 2. CNE/SDS PAGE analysis of OXPHOS proteins. Digitonin-solubilised proteins from human fibroblasts (A) and rat heart (B) mitochondria were separated by CNE in the first dimension (40 $\mu \mathrm{g}$ protein load) and by SDS PAGE in the second dimension. Subunits of the respiratory chain CI (NDUFA9), CII (SDHA, SDHB), CIII (Core1), CIV (Cox4) and CV ( $\alpha$ ) were immunodetected using specific antibodies. The dashed vertical lines in the distribution profiles below the western blots depict the main area of higher molecular weight forms of complex II $\left(\mathrm{Cll}_{\mathrm{hmw}}\right)$.

doi: 10.1371/journal.pone.0071869.g002

high molecular forms of $\mathrm{Cll}$ are a universal property of mammalian respiratory chain. Nevertheless, the mobility of $\mathrm{ClI}_{\mathrm{hmw}}$ in tissues was considerably different in comparison with cell lines. As shown in Figure 3B the main signal of the SDHA antibody in tissues was detected above $670 \mathrm{kDa}$, in the $\mathrm{MW}$ range of larger respiratory SCs (SDHB displayed an analogous distribution pattern, not shown). This was also observed on 2D CNE/SDS PAGE western blots (Figure 2B), where the signal of the CII SDHA and SDHB subunits was shifted to a higher MW. In contrast, other OXPHOS complexes were distributed comparably with the cultured cells (Figure 2A). Therefore, we performed in-gel activity staining of $\mathrm{Cll}$ in CNE gels to confirm the detected antibody signals in the cells and tissues. Figure 3C, D reveals that $\mathrm{ClI}_{\mathrm{hmw}}$ complexes were catalytically active and, indeed, differed between cells and tissues. In parallel, we performed in-gel CIV and CV activity staining to further analyse a possible co-migration or interaction with CII. In the case of cells, the dominant CIV activity signal could be ascribed to the CIV dimer $\left(\mathrm{CIV}_{\mathrm{D}}\right)$ (Figure $3 \mathrm{C}$ ), in the position corresponding to some of $\mathrm{CII}_{\mathrm{hmw}}$. The higher active CIV SCs did not co-migrate with the Cll signal. Thus, the size of $\mathrm{Cll}_{\mathrm{hmw}}$ in the cells more likely points to a mere co-migration of $\mathrm{Cll}$ homo-/heterooligomers with $\mathrm{CIV}_{\mathrm{D}}$, rather than to a genuine specific interaction between the OXPHOS complexes.
Interestingly, the CIV activity signals were shifted to the higher MW in tissues and overlapped with the activity signal of $\mathrm{ClI}_{\text {hmw }}$ (see Figure 3D). The interaction of CII with CIV or other OXPHOS complexes in the MW range $>1 \mathrm{MDa}$ thus cannot be excluded. The differences in the size of $\mathrm{Cl}_{\mathrm{hmw}}$ when comparing cells and tissues could suggest the existence of two major functional forms of CII SCs. In cells, they may be present largely as CII homo-oligomers, while in tissues, CII may possibly form SCs with other OXPHOS complexes. In-gel activity of monomeric and homo-oligomeric CV did indicate comigration or interaction with $\mathrm{ClI}_{\mathrm{hmw}}$ in tissues but not in cells (Figure 3C, D).

\section{$\mathrm{ClI}_{\mathrm{hmw}}$ formation depends on other respiratory chain complexes}

To learn more about possible interactions with other OXPHOS complexes, we performed CNE analysis of digitoninsolubilised mitochondria of human fibroblasts harbouring different types of OXPHOS defects that affect one or more respiratory chain complexes. We found that the selective deficiency of CIV (due to a SURF1 mutation, Figure 4B) or CV (due to a TMEM70 mutation, Figure 4C) did not affect the presence of $\mathrm{ClI}_{\text {hmw }}$ (Figure 4A). Similarly, the selective deficiency of $\mathrm{Cl}$ (an unknown mutation) was without any effect 
A
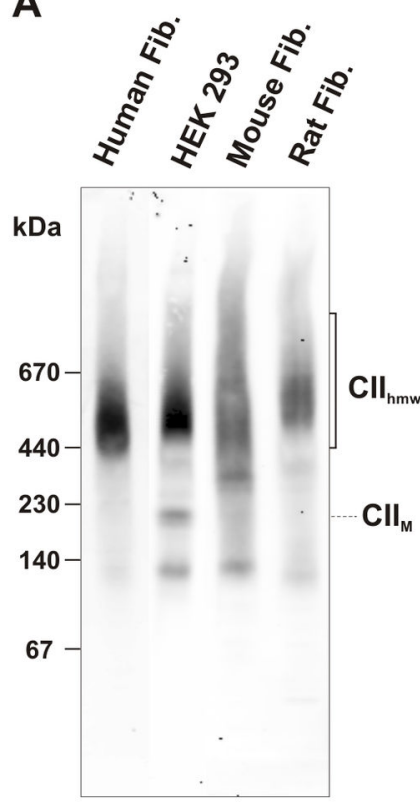

B
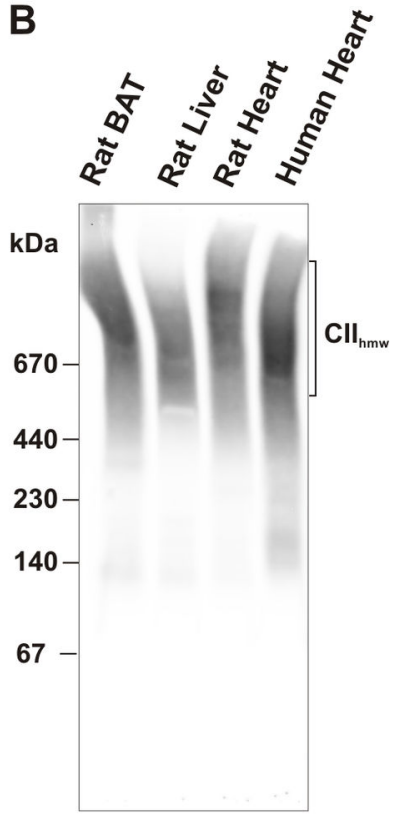

C

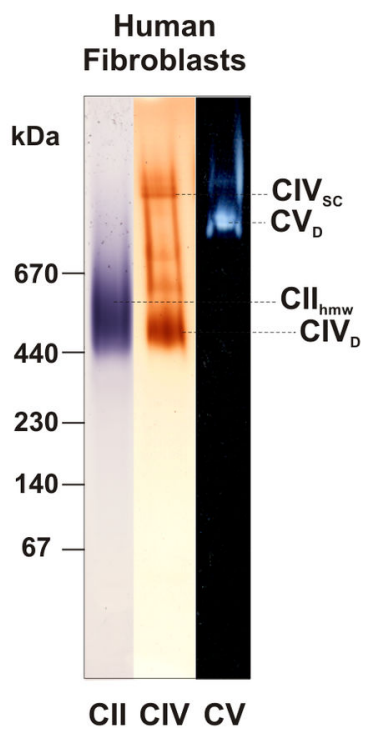

D

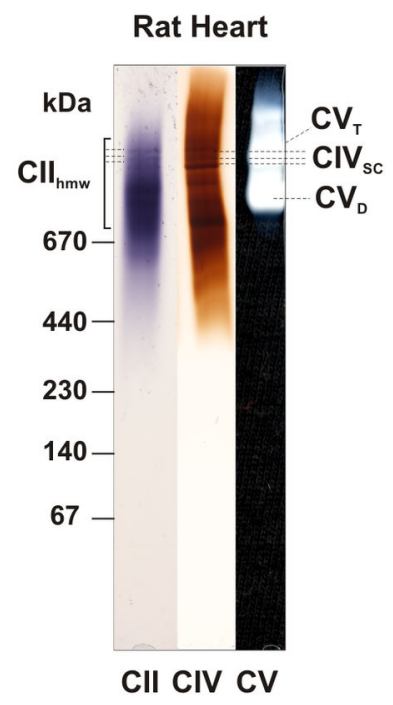

Figure 3. Comparison of $\mathrm{ClI}_{\mathrm{hmw}}$ in cells and tissues by western blot and in-gel activity staining. Mitochondria from different human and rodent cells $(A)$ and tissues $(B)$ were solubilised with digitonin ( $4 \mathrm{~g} / \mathrm{g}$ protein) and $20 \mu \mathrm{g}$ protein aliquots were separated using CNE. CII was immunodetected with the SDHA antibody. The activities of CIl (violet), CIV (brown) and CV (white) in CNE gels (protein load $50 \mu \mathrm{g}$ for cells and $40 \mu \mathrm{g}$ for tissues) are shown in human fibroblasts (C) and rat heart (D). The positions of higher molecular weight forms of $\mathrm{CII}\left(\mathrm{Cll}_{\mathrm{hmw}}\right)$, CII monomer $\left(\mathrm{CII}_{\mathrm{M}}\right)$, CIV dimer $\left(\mathrm{CIV}_{\mathrm{D}}\right)$ and its supercomplexes $\left(\mathrm{CIV}_{\mathrm{SC}}\right), \mathrm{CV}$ dimer $\left(\mathrm{CV} \mathrm{D}_{\mathrm{D}}\right)$ and tetramer $\left(\mathrm{CV}_{\mathrm{T}}\right)$ are indicated in the figure. Rat BAT, rat brown adipose tissue.

doi: 10.1371/journal.pone.0071869.g003

on the $\mathrm{ClI}_{\mathrm{hmw}}$ pattern. However, we obtained a different pattern in $\rho^{0}$ cells with depletion of mtDNA and thus lack of functional complexes I, III, IV and V [24]. Here, most of the $\mathrm{CII}_{\text {hmw }}$ signal disappeared and CII was present as unassembled subunits or monomer. This demonstrates the requirement of fully assembled Cll monomer for subsequent $\mathrm{ClI}_{\mathrm{hmw}}$ formation, and also its dependence on the preserved integrity of a fully functional respiratory chain (Figure 4A).

\section{$\mathrm{CII}_{\mathrm{hmw}}$ stability depends on very weak protein-protein interactions}

The fact that $\mathrm{CII}_{\mathrm{hmw}}$ are retained in CNE gels but dissociate in BNE gels (Figure 1) points to their rather labile nature. To analyse these interactions in more detail, we used CNE as before but with the CBG dye added to the sample (Figure $5 \mathrm{~A}$ ). In this experiment, $\mathrm{Cl}_{\mathrm{hmw}}$ dissociated into monomeric $\mathrm{Cll}$ due to the presence of CBG, while other respiratory chain SCs (CIV shown as an example) remained unaffected, apart from the fact that they were better focused due to the negative charge introduced by CBG. We therefore performed 2D CNE/CNE ${ }_{C B G}$ electrophoresis using $C B G$ to treat the gel slice after the CNE separation in the first dimension (Figure $5 \mathrm{~B}-\mathrm{F}$ ). As shown by western blots with the antibodies to SDHA and SDHB, all $\mathrm{Cl}_{\mathrm{hmw}}$ dissociated into $\mathrm{Cll}$ monomers after exposure to $\mathrm{CBG}$, that can bind to proteins due to its negative charge and thus interfered with weak non-covalent interactions. The main signal of $\mathrm{Cll}$ from the first dimension can again be observed within the MW range of $400-670 \mathrm{kDa}$. On the contrary, the SCs of Cl+III+IV were practically unaffected by CBG treatment (Figure 5E). Interestingly, the addition of CBG also partially affected oligomers of $\mathrm{CV}$, which dissociated to lower molecular weight forms corresponding to the $\mathrm{CV}$ monomer and the $\mathrm{F}_{1}$ subcomplex (Figure 5F).

To follow the potential differences between cultured cells and tissues, we examined the stability of $\mathrm{Cll}_{\mathrm{hmw}}$ from rat heart mitochondria in the presence of CBG. While we detected a complete breakdown of $\mathrm{ClI}_{\mathrm{hmw}}$ in the $\mathrm{CNE}$ gel after the addition of $\mathrm{CBG}$ to the sample (Figure $6 \mathrm{~A}$ ), most of the $\mathrm{ClI}_{\mathrm{hmw}}$ was unaffected under $2 \mathrm{D} \mathrm{CNE} / \mathrm{CNE}_{\mathrm{CBG}}$ conditions. Based on good reproducibility of the experiments, we can conclude that $\mathrm{CII}_{\mathrm{hmw}}$ do have higher MW and are more stable in tissues than in cultured cells. This may indicate that $\mathrm{Cll}$ has different interaction partners in tissues and cultured cells, and $\mathrm{ClI}_{\mathrm{hmw}}$ thus ultimately represents several structurally and functionally different SCs. As in cultured cells, CIV and its SCs were unaffected (Figure 6A, 6D), while CV partially dissociated from its higher forms to the monomeric and the $F_{1}$ sub-complex forms (Figure 6E). The sensitivity of $\mathrm{Cll}$ and $\mathrm{CV}$ to $\mathrm{CBG}$ indicates a similar type of mild interactions responsible for the formation of their respective higher molecular weight complexes. 
A

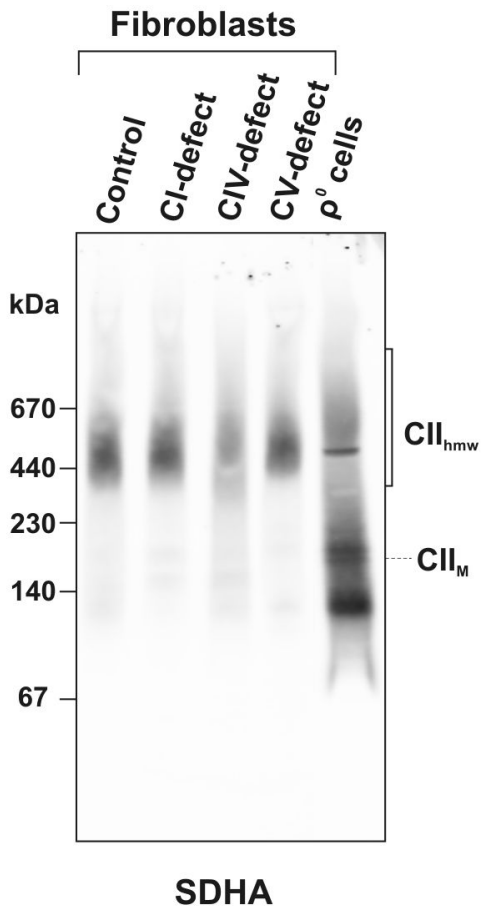

B

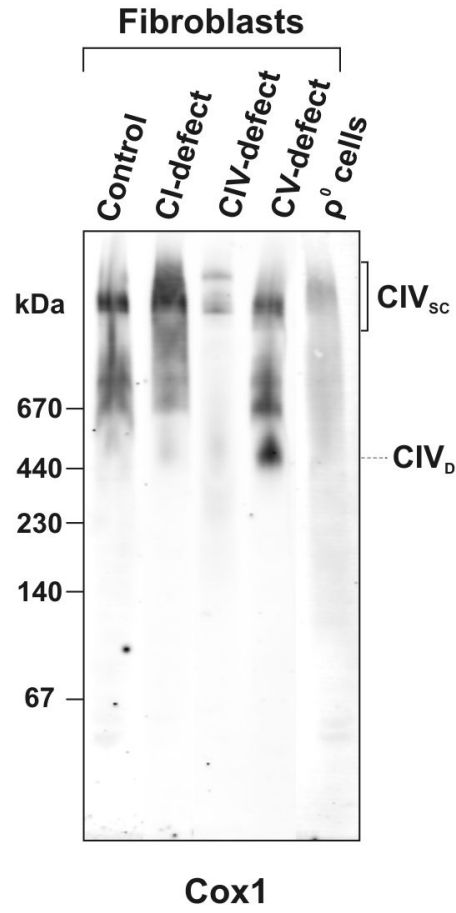

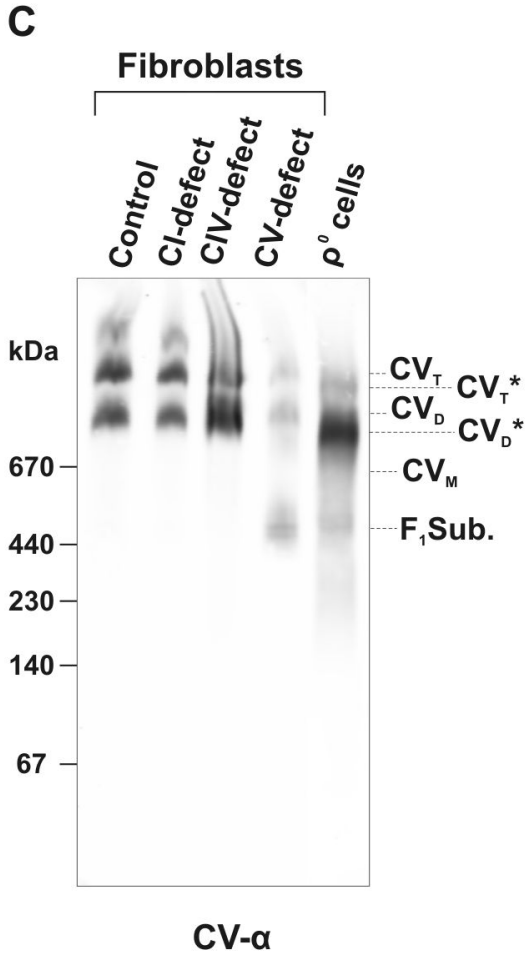

Figure 4. Presence of $\mathrm{ClI}_{\mathrm{hmw}}$ in human fibroblasts with different types of OXPHOS defects and $\rho^{0}$ cells. Digitonin-solubilised mitochondrial complexes were analysed by CNE (20 $\mu \mathrm{g}$ protein load) and immunodetected using antibodies to individual subunits: (A) CII, SDHA; (B) CIV, Cox1; (C) CV, a subunit. Positions of the Cll monomer $\left(\mathrm{Cll}_{\mathrm{M}}\right)$, high molecular weight forms of CII (Cll $\mathrm{hmw}_{\text {w }}$, CIV dimer $\left(\mathrm{CIV}_{\mathrm{D}}\right)$, supercomplexes of $\mathrm{CIV}\left(\mathrm{CIV}_{\mathrm{SC}}\right)$, $\mathrm{F}_{1}$ subcomplex of $\mathrm{CV}\left(\mathrm{F}{ }_{1}\right.$ Sub.), the monomer, dimer and tetramer of $\mathrm{CV}\left(\mathrm{CV} \mathrm{M}_{\mathrm{M}}\right.$, $\mathrm{CV}_{\mathrm{D}}$ and $\left.\mathrm{CV}_{\mathrm{T}}\right)$, and the dimer and tetramer of $\mathrm{CV}$ lacking the mtDNA-coded subunits $\left(\mathrm{CV}_{\mathrm{D}}{ }^{*}\right.$ and $\left.\mathrm{CV}_{\mathrm{T}}{ }^{*}\right)$ are marked.

doi: 10.1371/journal.pone.0071869.g004

\section{Cll co-immunoprecipitates with CV}

To investigate possible interactions between CII and CV by a different approach, we immunoprecipitated CV from rat heart mitochondria (Figure 7A) using a highly specific rabbit polyclonal antibody $\left(\mathrm{CV}-\mathrm{F}_{1}\right)$ to $\mathrm{CV}$ subunits $\alpha, \beta$ and $\mathrm{\gamma}$. The antibody immobilised to agarose beads immunoprecipitated whole $C V$, as evidenced by the presence of both $F_{1}$ ( $\alpha$ and $y$ ) and $F_{\circ}(a)$ subunits. The immunoprecipitate was free of $\mathrm{Cl}, \mathrm{CIII}$ and CIV subunits, but it contained a significant amount of the SDHA subunit of Cll. Similarly, SDHA was coimmunoprecipitated using $\mathrm{CV}-\mathrm{F}_{1}$ antibody and solubilised fibroblasts (Figure 7B). In a cross-experiment, we immunoprecipitated $\mathrm{Cll}$ from heart mitochondria using a highly specific monoclonal antibody against SDHA. The resulting immunoprecipitate contained $\mathrm{Cll}$ as well as the whole $\mathrm{CV}$ as revealed by the presence of subunits from $F_{1}$ and $F_{\circ}$ parts of CV (Figure 7A). In contrast, it was free of $\mathrm{Cl}$, CIII and CIV. Again, CV was also co-immunoprecipitated using SDHA antibody and solubilised fibroblasts (Figure 7B). As none of the commercially available antibodies against SDHC and SDHD we tested were reasonably specific, we cannot confirm the presence of fully assembled $\mathrm{Cll}$ in the precipitate. In principle, it is possible that only the two hydrophilic subunits SDHA and SDHB are present in the SC with CV. Notwithstanding, this result is compatible with recent data showing the presence of CIl as well as CV in the mitoK $\mathrm{ATP}_{\text {TP }}$ channel complex, whose size was found to be approximately $940 \mathrm{kDa}$, similarly to $\mathrm{ClI}_{\mathrm{hmw}}$ forms observed in tissues.

\section{CIl does not form SC with TCA cycle enzymes}

Cll can also potentially interact with components of the TCA cycle. We therefore used CNE to separate digitonin-solubilised $(4 \mathrm{~g} / \mathrm{g})$ rat heart mitochondria and subsequently analysed the lysate by western blotting for the presence and distribution pattern of individual TCA cycle enzymes, which were then compared with the distribution of Cll. We observed high molecular weight form complexes of fumarase and succinylCoA synthetase in the region above $670 \mathrm{kDa}$ (Figure $8 \mathrm{~A}$ ). Although they dissociated into lower molecular forms after the addition of CBG, as was the case for CII (Figure 8B), the CNE migration pattern for both fumarase and succinyl-CoA synthetase was slightly different from that of Cll, which does not support the existence of their direct interaction. Other digitonin-solubilised TCA cycle enzymes did not show any comigration with $\mathrm{Cll}$ on the CNE gels (not shown).

To check for the potential associations between $\mathrm{Cll}$ and other TCA cycle enzymes, we immunoprecipitated CIl from rat heart mitochondria using the monoclonal antibody against the 
A

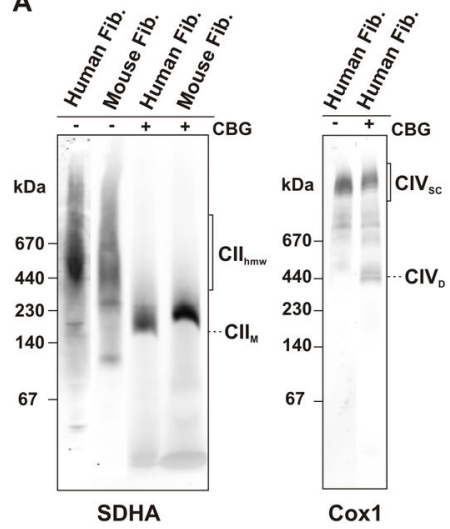

B

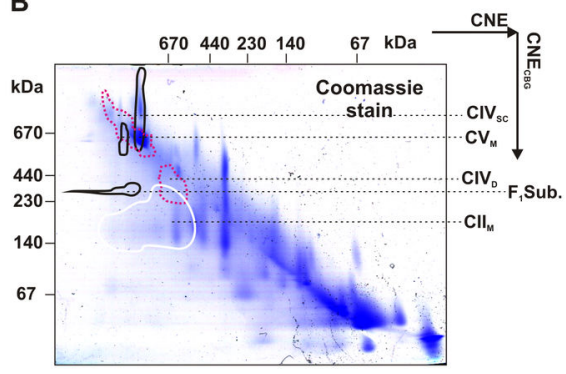

C

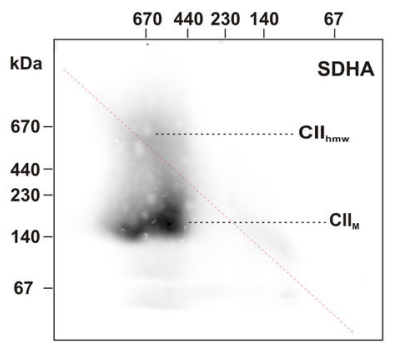

D

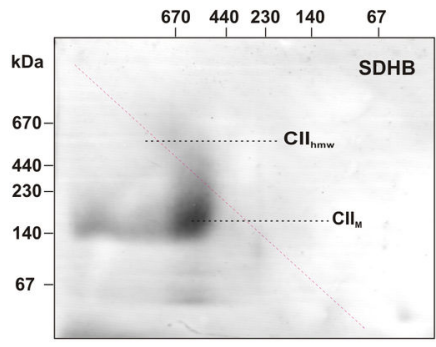

E

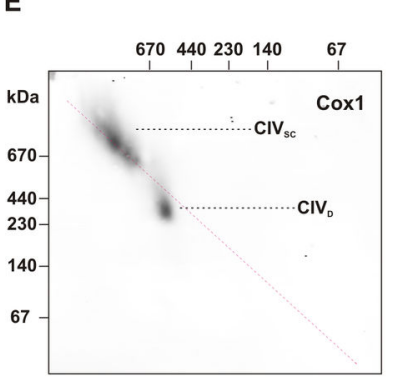

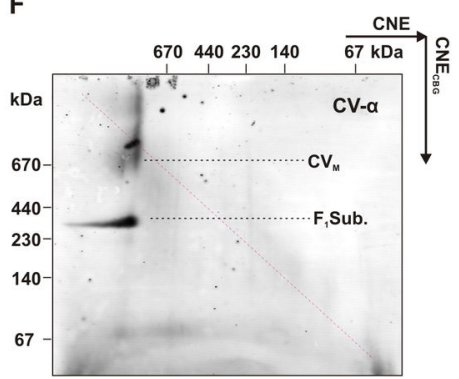

Figure 5. Low stability of $\mathrm{Cll}_{\mathrm{hmw}}$ in fibroblasts. (A) Digitonin-solubilised (4 g/g protein; $20 \mu \mathrm{g}$ protein load) mitochondrial proteins from control human fibroblasts or control mouse fibroblasts were resolved by CNE with (+) or without (-) CBG. (B-F) Twodimensional $\mathrm{CNE} / \mathrm{CNE}_{\mathrm{CBG}}$ analysis of mitochondrial proteins from control fibroblasts (50 $\mathrm{\mu g}$ protein load). After separation of mitochondrial proteins with CNE, the gel slices were incubated in CBG and subjected to CNE in the second dimension. One gel was stained in Coomassie blue stain and identical duplicate gel was used for western blot. The positions of individual OXPHOS complexes are highlighted on the stained gel $(\mathrm{B})$ according to their immunodetection: full white line, $\mathrm{CII}$ monomer $\left(\mathrm{ClI}_{\mathrm{M}}\right)$; dashed red line, $\mathrm{CIV}$ dimer $\left(\mathrm{CIV}_{\mathrm{D}}\right)$ and supercomplexes of $\mathrm{CIV}\left(\mathrm{CIV}_{\mathrm{SC}}\right)$; full black line, $\mathrm{F}_{1}$ subcomplex of $\mathrm{CV}\left(\mathrm{F}_{1}\right.$ Sub.) and monomer of $\mathrm{CV}\left(\mathrm{CV} \mathrm{V}_{\mathrm{M}}\right)$ based on the signals of SDHA (C), SDHB (D), Cox1 (E) and CV- $\alpha(F)$ subunits.

doi: 10.1371/journal.pone.0071869.g005

SDHA subunit as above. The resulting immunoprecipitated CII contained no other TCA cycle enzymes, namely $\alpha-$ ketoglutarate dehydrogenase (subunit E1), aconitase, fumarase, citrate synthase, isocitrate dehydrogenase (subunit $\alpha$ ), succinyl-CoA synthetase (subunit $\alpha$ ) or malate dehydrogenase (Figure 8B).

\section{Discussion}

The key finding of this study is the discovery of Cll propensity to form higher molecular structures $\left(\mathrm{Cll}_{\mathrm{hmw}}\right)$ in the IMM. We demonstrated that under sufficiently mild conditions, Cll associates into $\mathrm{Cll}_{\mathrm{hmw}}$ forms in both mammalian cultured cells and tissues. As the representative cell line/tissue we used human fibroblasts and rat heart, and we have clearly shown that $\mathrm{CII}_{\mathrm{hmw}}$ are present regardless of the species (rat, mouse, human), tissue type (heart, liver, brown adipose tissue) or the origin of the cell line (fibroblasts, kidney cells). As such, $\mathrm{Cl}_{\mathrm{hmw}}$ can be found in mitochondria with a wide range of content of the respiratory chain complexes. The interactions responsible for $\mathrm{Cll}_{\mathrm{hmw}}$ formation must be rather weak as the supramolecular structures are not retained under the conditions of the commonly used native electrophoretic techniques, such as BNE or hrCNE $[26,28]$, where either negatively charged CBG or additional detergents are present and, presumably, disrupt the weak interactions responsible for $\mathrm{ClI}_{\mathrm{hmw}}$ formation. Thus, these complexes can only be visualised using the CNE electrophoretic system, where proteins migrate according to their intrinsic charge routinely lost by the charged dyes or detergents used to introduce the net charge to the protein micelles formed during the solubilisation of the membrane. Despite the lower resolution of CNE in comparison with other native electrophoretic systems [31], we have shown that $\mathrm{CII}_{\mathrm{hmw}}$ forms differ in their apparent molecular mass between tissues (500 - over $1000 \mathrm{kDa}$ ) and cultured cells (400-670 kDa). The reasons for this difference are not immediately obvious. Possibly, this may be the effect of detergent (i.e. digitonin) and its concentrations used for solubilisation of proteins from the IMM. Apart from the critical micellar concentration [32], the ratio of the detergent and the protein can also dictate the outcome of 
A

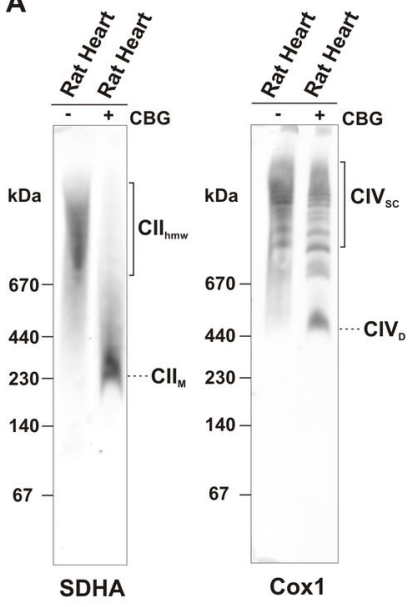

B

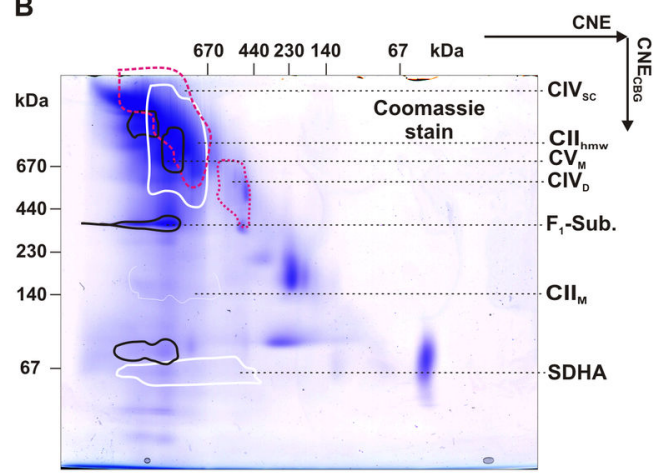

C

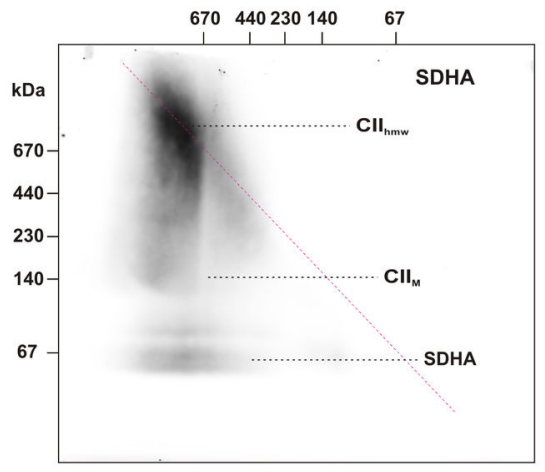

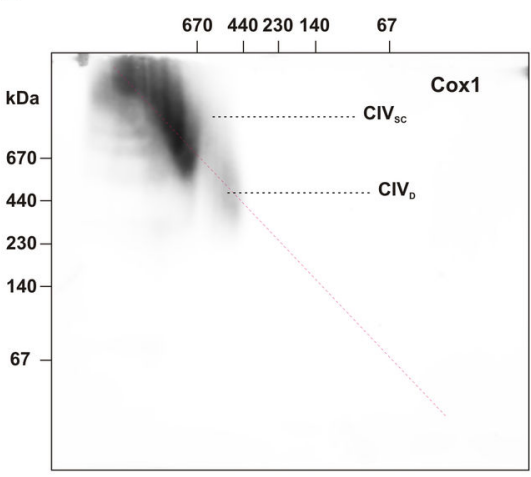

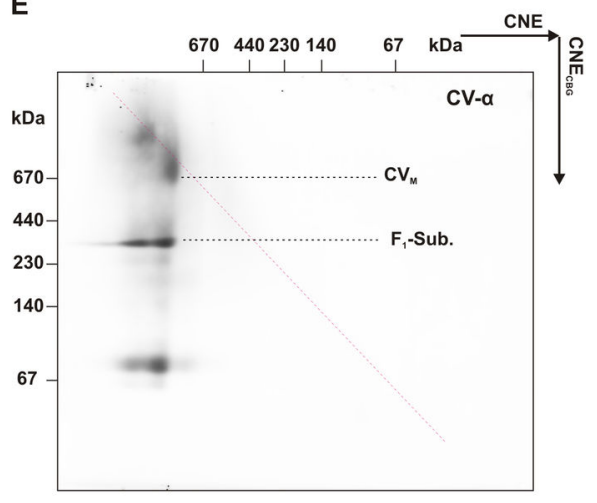

Figure 6. Low stability of $\mathrm{ClI}_{\mathrm{hmw}}$ in rat heart. (A) Digitonin-solubilised $(4 \mathrm{~g} / \mathrm{g}$ protein, $20 \mu \mathrm{g}$ protein load) mitochondrial proteins from rat heart mitochondria were resolved by $\mathrm{CNE}$ with (+) or without (-) CBG. (B-F) Two-dimensional $\mathrm{CNE}_{\text {(CNE }} \mathrm{CBG}_{\text {analysis of }}$ mitochondrial proteins from rat heart $(40 \mu \mathrm{g}$ protein load). After separation of mitochondrial proteins with $\mathrm{CNE}$, the gel slices were incubated in CBG and subjected to CNE in the second dimension. One gel was stained in Coomassie blue stain and identical duplicate gel was used for western blot. The positions of individual OXPHOS complexes are highlighted on the stained gel (B) according to their immunodetection: full white line, $\mathrm{Cll}$ monomer $\left(\mathrm{ClI}_{\mathrm{M}}\right)$, high molecular weight forms of $\mathrm{Cll}\left(\mathrm{Cl} \mathrm{hmw}_{\mathrm{h}}\right)$, and the SDHA subunit of $\mathrm{Cll}$; dashed red line, $\mathrm{CIV}$ dimer $\left(\mathrm{CIV}_{\mathrm{D}}\right)$ and supercomplexes of $\mathrm{CIV}\left(\mathrm{CIV}_{\mathrm{SC}}\right)$; full black line, $\mathrm{F}_{1}$ subcomplex of $\mathrm{CV}\left(\mathrm{F}_{1} \mathrm{Sub}\right.$.) and monomer of $\mathrm{CV}\left(\mathrm{CV}_{\mathrm{M}}\right)$ based on the signals of SDHA $(\mathrm{C}), \operatorname{Cox} 1(\mathrm{D})$, and $\mathrm{CV}-\alpha(\mathrm{E})$ subunits.

doi: 10.1371/journal.pone.0071869.g006

the solubilisation process. As tissues display higher density of mitochondria than cultured cells, the use of the same detergent/protein ratio for both may yield different results when resolving the mitochondrial SCs. Another possible reason for the different mobility of $\mathrm{Cll}_{\mathrm{hmw}}$ from the two sources could be a different phospholipid composition of the IMM between cells and tissues, although the recent work indicates similarities in the relative abundance of mitochondrial phospholipids in tissues and cultured cells $[33,34]$. Ultimately, this difference may simply reflect a higher number of OXPHOS complexes in the IMM [33,35] and different energetic demands of tissues when compared with cells that lead to a higher probability of CII uptake into larger structures in the tissue mitochondria. Importantly, the observed differences between cells and tissues in $\mathrm{ClI}_{\mathrm{hmw}}$ size and stability as well as their dependence on mtDNA depletion, support the view that they reflect biological properties of complex II and do not represent an artefact of CNE electrophoresis.

When assessing the stability of $\mathrm{Cll}_{\mathrm{hmw}}$ complexes, we detected the $\mathrm{ClI}_{\mathrm{hmw}}$ as the dominant structural form of $\mathrm{Cll}$ in digitonin solubilisates under the CNE separation conditions. The presence of either detergents ( $n$-dodecyl- $\beta$-D-maltoside, deoxycholic acid) or CBG in the running buffer, i.e. conditions usually used to achieve better separation and resolution in the hrCNE and BNE electrophoretic systems, readily dissociated $\mathrm{ClI}_{\text {hmw }}$ in both cells and tissues to CII monomers and individual subunits. Even the very low CBG concentration added to the sample $(0.02 \%, 50$-fold less than used in BNE samples) was sufficient for the complete $\mathrm{Cll}_{\mathrm{hmw}}$ dissociation. Similarly, incubation of the CNE gel slice with separated $\mathrm{CII}_{\mathrm{hmw}}$ in a CBG solution also caused a partial dissociation of the $\mathrm{ClI}_{\mathrm{hmw}}$ structures, mainly in cultured cells. The addition of CBG to the 
A

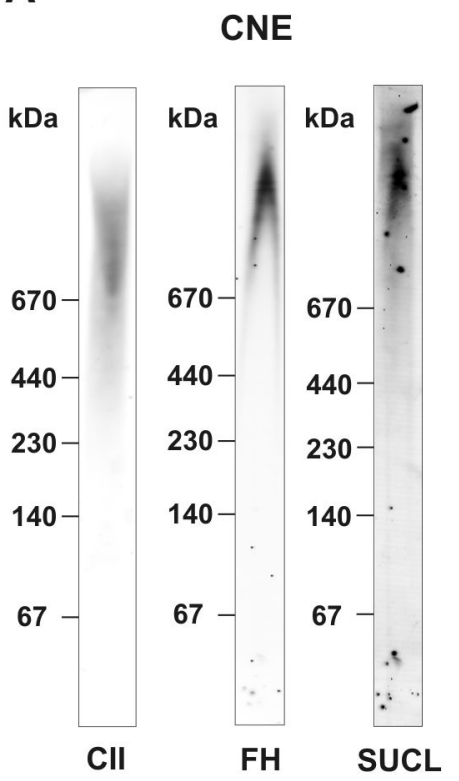

B

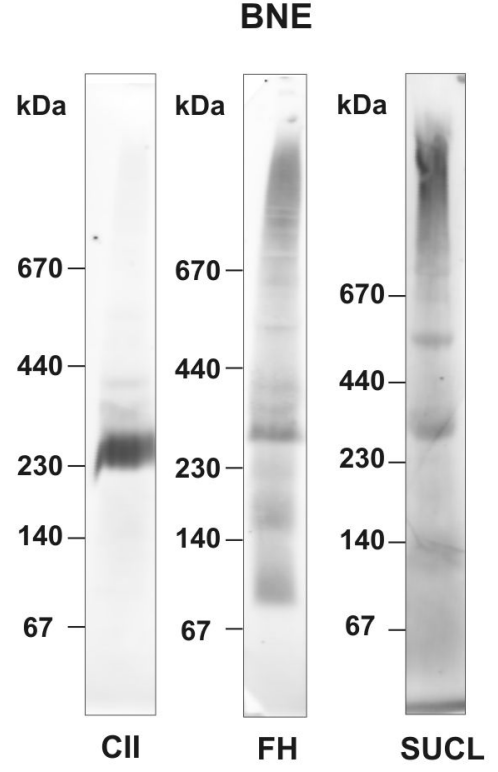

C

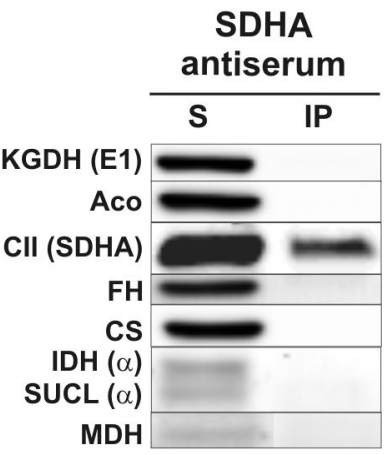

Figure 8. Cll does not associate with other components of TCA cycle. (A) Mitochondrial membrane proteins from rat heart were solubilised with digitonin ( $4 \mathrm{~g} / \mathrm{g}$ protein) and $20 \mu \mathrm{g}$ protein aliquots separated using CNE. SDHA subunit of CII (CII), fumarase $(\mathrm{FH})$ and subunit $\alpha$ of succinyl-CoA synthetase (SUCL) were detected with specific antibodies. (B) After digitonin solubilisation of mitochondria from rat heart, CIl was immunoprecipitated with anti-SDHA antibody (SDHA antiserum). Proteins in the immunoprecipitate (IP) and solubilisate (S) were separated by SDS PAGE and analysed for the presence of individual components of the TCA cycle: a-ketoglutarate dehydrogenase subunit E1, KGDH (E1); aconitase, Aco; CII, SDHA; fumarase, FH; citrate synthase, CS; isocitrate dehydrogenase subunit $\alpha$, IDH ( $\alpha$ ); succinyl-CoA synthetase (subunit $\alpha$ ), SUCL ( $\alpha$ ); malate dehydrogenase, $\mathrm{MDH}$.

doi: 10.1371/journal.pone.0071869.g008

A

B

\section{Rat Heart}
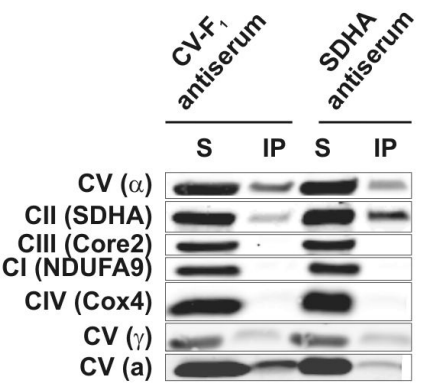

\section{Fibroblasts}

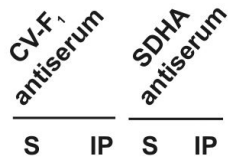

CII (SDHA)

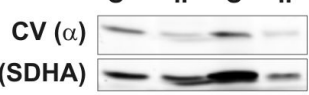

Figure 7. Cll and CV co-immunoprecipitates. After digitonin solubilisation of mitochondria from the rat heart $(A)$ and human fibroblasts (B), CV was immunoprecipitated with antibodies to its $F_{1}$ part and $\mathrm{Cll}$ with anti-SDHA. Proteins in the immunoprecipitate (IP) and solubilisate (S) were separated by SDS PAGE and individual subunits of OXPHOS complexes detected as indicated with antibodies to $\mathrm{Cl}$, NDUFA9; CII, SDHA; CIII, Core2; CIV, Cox4; CV, $\alpha, y, a$.

doi: 10.1371/journal.pone.0071869.g007 sample/solution induces a dissociation effect by binding of the dye to proteins surface and introduction of a negative charge that can affect intermolecular interactions. Apparently, this process is more effective in solution than in the gel slice.

To understand the $\mathrm{ClI}_{\text {hmw }}$ function, it is important to define $\mathrm{Cll}$ interaction partners in $\mathrm{Cll}_{\text {hmw }}$. The most obvious candidates would be other OXPHOS complexes, but the putative presence of $\mathrm{Cll}$ in the SCs with other OXPHOS complexes is still a matter of discussion. For example, single particle electron microscopy and X-ray imaging structural studies seem to contradict such idea $[36,37]$. These methods did not reveal the presence of Cll in any type of SCs. It should be noted, though, that due to its relatively small size, CII may simply be below the detection limit of these techniques. Similarly, studies of the assembly kinetics of the $\mathrm{Cl}+\mathrm{CIII+CIV} \mathrm{SC}$ did not reveal any participation of $\mathrm{Cll}$ in this process [38]. On the other hand, at least some immunocapture and electrophoretic experiments demonstrated the existence of a large respirasome comprising respiratory chain complexes, including $\mathrm{Cll}$, as well as mobile electron carriers [17]. We therefore attempted to find any indication of the interaction between $\mathrm{Cll}$ and other OXPHOS complexes. CNE analysis and in-gel activity staining in CNE gels pointed to a possible interaction with CIV or CV, but due to the low resolution of protein bands in the CNE gels it is hard to interpret this as genuine interactions. In the MW range 400- 
$670 \mathrm{kDa}$ where $\mathrm{CII}_{\mathrm{hmw}}$ are found in the cells, many other protein complexes and small SCs migrate. It is more likely that $\mathrm{CII}_{\mathrm{hmw}}$ represents $\mathrm{Cll}$ oligomers co-migrating with $\mathrm{CV}$ or $\mathrm{CIV}_{\mathrm{D}}$, as incorporation of $\mathrm{Cll}$ into other complexes migrating in this range would require a shift in the electrophoretic mobility of the resulting SCs towards MW greater by at least $140 \mathrm{kDa}$, i.e. the molecular weight of the CII monomer. On the other hand, $\mathrm{CII}_{\mathrm{hmw}}$ in the tissues with size over $1 \mathrm{MDa}$ may represent $\mathrm{Cll}$ as a part of OXPHOS SCs.

In another attempt to detect specific OXPHOS interacting partner(s) for CII, we studied cell lines with both isolated and combined deficiencies of OXPHOS complexes. With one of the interaction partners missing, the $\mathrm{Cll}_{\mathrm{hmw}}$ signal would be decreased or undetectable in the respective cell line. Such interdependency is well described for canonical OXPHOS SCs $[12,17,38]$. However, in our experiments, the levels and position of $\mathrm{Cll}_{\mathrm{hmw}}$ appear to be unchanged in cells with isolated defects of $\mathrm{Cl}$, CIV or $\mathrm{CV}$, presenting additional evidence that no stable interaction is formed between $\mathrm{Cll}$ and other OXPHOS complexes. On the other hand, when we analysed $\rho^{0}$ cells lacking mtDNA, unassembled subunits predominated over the Cll monomer, and the $\mathrm{Cll}_{\text {hmw }}$ structures were almost absent. The absence of the mtDNA-encoded subunits impedes the assembly and function of OXPHOS in $\rho^{0}$ cells [39]. Because CII is entirely encoded by the nuclear DNA, it was considered to be unchanged, but a recent study by Mueller et al. [40] reports a decreased level of $\mathrm{CII}$ with its activity reduced to $12 \%$. Although the synthesis of the nuclear encoded subunits is unaffected in $\rho^{0}$ cells, mitochondrial protein import is disturbed as a consequence of decreased levels of ATP and the Tim44 protein, an essential effector of mitochondrial protein import [41]. Our experiments suggest that the $\mathrm{Cll}$ and $\mathrm{Cl}_{\mathrm{hmw}}$ assembly depends on fully active mitochondria and the OXPHOS complexes of the IMM.

Immunoprecipitation was another independent approach we used to detect possible Cll interaction partners. Here we identified $\mathrm{CV}$ as a plausible interaction partner of $\mathrm{Cll}$ both in cultured cells and tissues. Generally, immunoprecipitation is more sensitive and selective than electrophoresis and can reveal rather weak interactions. Based on our experiments, we can conclude that $\mathrm{CII}$, at least partially, co-immunoprecipitates with $\mathrm{CV}$, constituting possibly a part of the mitoK $\mathrm{K}_{\text {ATP }}$ channel described in recent studies. Although the role for $\mathrm{CII}$ in mitoK $_{\text {ATP }}$ remains elusive, it was shown that $\mathrm{SDH}$ inhibitors modulate the channel activity and subsequently the process of ischemic preconditioning $[18,42]$. Only $0.4 \%$ of the Cll present in mitochondria is necessary to activate the mitoK $\mathrm{ATP}_{\text {TP }}$ and the inhibition of such a small portion of $\mathrm{Cll}$ has no effect on the overall Cll activity in OXPHOS [43]. The interaction of Cll with $\mathrm{CV}$ is also not in conflict with our results with $\rho^{0}$ cells, as $\mathrm{CV}$ is assembled in $\rho^{0}$ cells, except for the two mtDNA-encoded subunits, ATP6 and ATP8 [44]. Such form of CV (lacking the two subunits) is sufficient for the survival of $\rho^{0}$ cells as it can hydrolyse ATP produced by glycolysis and allow for the maintenance of the transmembrane $\mathrm{H}^{+}$gradient by the electrogenic exchange of ATP for ADP by adenine nucleotide translocator $[45,46]$.

An attractive proposal may be that CII may interact with other proteins from the TCA cycle, forming an organised multienzyme cluster. As the only membrane bound component of the TCA metabolism, CIl would represent an anchor for the docking of TCA metabolism to the IMM into the spatial proximity of OXPHOS, in accordance with the known association of soluble TCA cycle enzymes with the mitochondrial membrane [47]. The existence of the metabolon composed of at least several TCA cycle proteins has been suggested $[47,48]$. However, most of the evidence points to the interactions of malate dehydrogenase, citrate synthase and, potentially, aconitase $[19,20]$. To date, no interaction involving CIl has been demonstrated. Native electrophoretic systems represent a plausible model to study such interactions; although they involve solubilisation of membrane proteins by detergents, the solubilisates of whole mitochondria contain also matrix proteins. Naturally, any such interactions may be disrupted during the analysis. Here, crosslinking may help to capture such interactions in the future studies. Despite the fact that we did not identify any interacting partners for CIl among the tested TCA cycle proteins, this deserves additional work as such interactions would appear functionally plausible.

It is possible that interactions of Cll other than the one detected with $\mathrm{CV}$ do exist, and that such interactions may not even necessarily involve the whole of CII. For example, Gebert et al. [49] have published that the Sdh3 subunit of yeast CII (SDHC in mammals) has a dual function in mitochondria. It acts as a structural and functional subunit of $\mathrm{Cll}$ and also plays a role in the biogenesis and assembly of the TIM22 complex via a direct interaction between Sdh3 and Tim18. Therefore, we cannot exclude that other Cll subunits would have specific functions outside of the OXPHOS system. Notwithstanding these potential interactions of CII, our data lead to the conclusion that $\mathrm{Cll}$ does form high molecular weight assemblies, but these structures are unlikely to represent traditional respiratory supercomplexes with $\mathrm{Cl}$, CIII and CIV as proposed previously by Acin-Perez et al. [17]. At least, some of these interactions are complexes with $\mathrm{CV}$ where $\mathrm{Cll}$ plays a role as a regulatory component of mitoK $\mathrm{ATP}_{\mathrm{A}}$ channel [42]. To summarise, our findings are consistent with the emerging notion that the individual OXPHOS complexes, or they subunits, have a role that may go beyond direct involvement in the mitochondrial bioenergetics.

\section{Author Contributions}

Conceived and designed the experiments: NK TM HN JN JH. Performed the experiments: NK TM HN EH. Analyzed the data: NK TM HN EH MV PP JH. Contributed reagents/materials/ analysis tools: KH KK JR. Wrote the manuscript: NK TM PP JN $\mathrm{JH}$. 


\section{References}

1. Cecchini G (2003) Function and structure of complex II of the respiratory chain. Annu Rev Biochem 72: 77-109. doi:10.1146/ annurev.biochem.72.121801.161700. PubMed: 14527321.

2. Sun $F$, Huo $X$, Zhai YJ, Wang AJ, Xu JX et al. (2005) Crystal structure of mitochondrial respiratory membrane protein complex II. Cell 121: 1043-1057. doi:10.1016/j.cell.2005.05.025. PubMed: 15989954.

3. Brière JJ, Favier J, El Ghouzzi V, Djouadi F, Bénit P et al. (2005) Succinate dehydrogenase deficiency in human. Cell Mol Life Sci 62: 2317-2324. doi:10.1007/s00018-005-5237-6. PubMed: 16143825.

4. Bardella C, Pollard PJ, Tomlinson I (2011) SDH mutations in cancer. Biochim Biophys Acta 1807: 1432-1443. doi:10.1016/j.bbabio. 2011.07.003. PubMed: 21771581

5. Burnichon N, Brière JJ, Libé R, Vescovo L, Rivière $\mathrm{J}$ et al. (2010) SDHA is a tumor suppressor gene causing paraganglioma. Hum Mol Genet 19: 3011-3020. doi:10.1093/hmg/ddq206. PubMed: 20484225.

6. Perry CG, Young WF Jr, McWhinney SR, Bei T, Stergiopoulos S et al. (2006) Functioning paraganglioma and gastrointestinal stromal tumor of the jejunum in three women: syndrome or coincidence. Am J Surg Pathol 30: 42-49. doi:10.1097/01.pas.0000178087.69394.9f. PubMed: 16330941.

7. Ricketts C, Woodward ER, Killick P, Morris MR, Astuti D et al. (2008) Germline SDHB mutations and familial renal cell carcinoma. J Natl Cancer Inst 100: 1260-1262. doi:10.1093/jnci/djn254. PubMed: 18728283.

8. Kluckova K, Bezawork-Geleta A, Rohlena J, Dong L, Neuzil J (2013) Mitochondrial complex II, a novel target for anti-cancer agents. Biochim Biophys Acta 1827: 552-564. doi:10.1016/j.bbabio.2012.10.015. PubMed: 23142170

9. Ghezzi D, Goffrini P, Uziel G, Horvath R, Klopstock T et al. (2009) SDHAF1, encoding a LYR complex-II specific assembly factor, is mutated in SDH-defective infantile leukoencephalopathy. Nat Genet 41: 654-656. doi:10.1038/ng.378. PubMed: 19465911.

10. Shi YB, Ghosh MC, Tong WH, Rouault TA (2009) Human ISD11 is essential for both iron-sulfur cluster assembly and maintenance of normal cellular iron homeostasis. Hum Mol Genet 18: 3014-3025. doi: 10.1093/hmg/ddp239. PubMed: 19454487

11. Hao HX, Khalimonchuk O, Schraders M, Dephoure N, Bayley JP et al. (2009) SDH5, a gene required for flavination of succinate dehydrogenase, is mutated in paraganglioma. Science 325: 1139-1142. doi:10.1126/science.1175689. PubMed: 19628817.

12. Bianchi C, Genova ML, Parenti Castelli G, Lenaz G (2004) The mitochondrial respiratory chain is partially organized in a supercomplex assembly: kinetic evidence using flux control analysis. J Biol Chem 279: 36562-36569. doi:10.1074/jbc.M405135200. PubMed: 15205457.

13. Shibata N, Kobayashi M (2008) The role for oxidative stress in neurodegenerative diseases. Brain Nerve 60: 157-170. PubMed: 18306664.

14. Strauss M, Hofhaus G, Schröder RR, Kühlbrandt W (2008) Dimer ribbons of ATP synthase shape the inner mitochondrial membrane. EMBO J 27: 1154-1160. doi:10.1038/emboj.2008.35. PubMed: 18323778.

15. Schägger H, Pfeiffer K (2000) Supercomplexes in the respiratory chains of yeast and mammalian mitochondria. EMBO J 19: 1777-1783. doi:10.1093/emboj/19.8.1777. PubMed: 10775262

16. Wittig I, Schägger H (2009) Native electrophoretic techniques to identify protein-protein interactions. Proteomics 9: 5214-5223. doi:10.1002/ pmic.200900151. PubMed: 19834896

17. Acín-Pérez R, Fernández-Silva $P$, Peleato $M L$, Pérez-Martos $A$, Enriquez JA (2008) Respiratory active mitochondrial supercomplexes. Mol Cell 32: 529-539. doi:10.1016/j.molcel.2008.10.021. PubMed: 19026783.

18. Ardehali H, Chen Z, Ko Y, Mejía-Alvarez R, Marbán E (2004) Multiprotein complex containing succinate dehydrogenase confers mitochondrial ATP-sensitive K+ channel activity. Proc Natl Acad Sci U S A 101: 11880-11885. doi:10.1073/pnas.0401703101. PubMed: 15284438 .

19. Meyer FM, Gerwig J, Hammer E, Herzberg C, Commichau FM et al. (2011) Physical interactions between tricarboxylic acid cycle enzymes in Bacillus subtilis: evidence for a metabolon. Metab Eng 13: 18-27. doi: 10.1016/j.ymben.2010.10.001. PubMed: 20933603

20. Vélot C, Mixon MB, Teige M, Srere PA (1997) Model of a quinary structure between Krebs TCA cycle enzymes: a model for the metabolon. Biochemistry 36: 14271-14276. doi:10.1021/bi972011j. PubMed: 9400365

21. Kovářová N, Cížková Vrbacká $A$, Pecina $P$, Stránecký V, Pronicka E et al. (2012) Adaptation of respiratory chain biogenesis to cytochrome c oxidase deficiency caused by SURF1 gene mutations. Biochim Biophys
Acta 1822: 1114-1124. doi:10.1016/j.bbadis.2012.03.007. PubMed: 22465034

22. Piekutowska-Abramczuk D, Magner M, Popowska E, Pronicki M Karczmarewicz E et al. (2009) SURF1 missense mutations promote a mild Leigh phenotype. Clin Genet 76: 195-204. doi:10.1111/j. 1399-0004.2009.01195.x. PubMed: 19780766.

23. Honzík T, Tesarová M, Mayr JA, Hansíková H, Jesina P et al. (2010) Mitochondrial encephalocardio-myopathy with early neonatal onset due to TMEM70 mutation. Arch Dis Child 95: 296-301. doi:10.1136/adc. 2009.168096. PubMed: 20335238.

24. King MP, Attardi G (1996) Isolation of human cell lines lacking mitochondrial DNA. Methods Enzymol 264: 304-313. doi:10.1016/ S0076-6879(96)64029-4. PubMed: 8965704.

25. Bentlage HA, Wendel U, Schägger $H$, ter Laak HJ, Janssen AJ et al. (1996) Lethal infantile mitochondrial disease with isolated complex I deficiency in fibroblasts but with combined complex I and IV deficiencies in muscle. Neurology 47: 243-248. doi:10.1212/WNL. 47.1.243. PubMed: 8710086.

26. Wittig I, Braun HP, Schägger H (2006) Blue native PAGE. Nat Protoc 1: 418-428. doi:10.1038/nprot.2006.62. PubMed: 17406264

27. Mrácek T, Pecinová A, Vrbacký M, Drahota Z, Houstek J (2009) High efficiency of ROS production by glycerophosphate dehydrogenase in mammalian mitochondria. Arch Biochem Biophys 481: 30-36. doi: 10.1016/j.abb.2008.10.011. PubMed: 18952046.

28. Wittig I, Karas M, Schägger H (2007) High resolution clear native electrophoresis for in-gel functional assays and fluorescence studies of membrane protein complexes. Mol Cell Proteomics 6: 1215-1225. doi: 10.1074/mcp.M700076-MCP200. PubMed: 17426019.

29. Schägger $H$, von Jagow $G$ (1987) Tricine-sodium dodecyl sulfatepolyacrylamide gel electrophoresis for the separation of proteins in the range from 1 to $100 \mathrm{kDa}$. Anal Biochem 166: 368-379. doi: 10.1016/0003-2697(87)90587-2. PubMed: 2449095

30. Moradi-Ameli M, Godinot C (1983) Characterization of monoclonal antibodies against mitochondrial F1-ATPase. Proc Natl Acad Sci U S A 80: 6167-6171. doi:10.1073/pnas.80.20.6167. PubMed: 6194526.

31. Wittig I, Schägger H (2005) Advantages and limitations of clear-native PAGE. Proteomics 5: 4338-4346. doi:10.1002/pmic.200500081. PubMed: 16220535

32. Ko YH, Delannoy M, Hullihen J, Chiu W, Pedersen PL (2003) Mitochondrial ATP synthasome. Cristae-enriched membranes and a multiwell detergent screening assay yield dispersed single complexes containing the ATP synthase and carriers for Pi and ADP/ATP. J Biol Chem 278: 12305-12309. doi:10.1074/jbc.C200703200. PubMed: 12560333.

33. Lenaz G, Genova ML (2012) Supramolecular organisation of the mitochondrial respiratory chain: a new challenge for the mechanism and control of oxidative phosphorylation. Adv Exp Med Biol 748: 107-144. doi:10.1007/978-1-4614-3573-0_5. PubMed: 22729856.

34. Rosca M, Minkler P, Hoppel CL (2011) Cardiac mitochondria in heart failure: normal cardiolipin profile and increased threonine phosphorylation of complex IV. Biochim Biophys Acta 1807: 1373-1382. doi:10.1016/j.bbabio.2011.02.003. PubMed: 21320465.

35. Benard G, Faustin B, Passerieux E, Galinier A, Rocher C et al. (2006) Physiological diversity of mitochondrial oxidative phosphorylation. Am J Physiol Cell Physiol 291: C1172-C1182. doi:10.1152/ajpcell. 00195.2006. PubMed: 16807301.

36. Dudkina NV, Eubel H, Keegstra W, Boekema EJ, Braun HP (2005) Structure of a mitochondrial supercomplex formed by respiratory-chain complexes I and III. Proc Natl Acad Sci U S A 102: 3225-3229. doi: 10.1073/pnas.0408870102. PubMed: 15713802.

37. Schäfer E, Seelert H, Reifschneider NH, Krause F, Dencher NA et al. (2006) Architecture of active mammalian respiratory chain supercomplexes. J Biol Chem 281: 15370-15375. doi:10.1074/ jbc.M513525200. PubMed: 16551638.

38. Moreno-Lastres D, Fontanesi F, García-Consuegra I, Martín MA, Arenas J et al. (2012) Mitochondrial complex I plays an essential role in human respirasome assembly. Cell Metab 15: 324-335. doi:10.1016/ j.cmet.2012.01.015. PubMed: 22342700 .

39. Chevallet M, Lescuyer P, Diemer H, van Dorsselaer A, Leize-Wagner $E$ et al. (2006) Alterations of the mitochondrial proteome caused by the absence of mitochondrial DNA: A proteomic view. Electrophoresis 27: 1574-1583. doi:10.1002/elps.200500704. PubMed: 16548050.

40. Mueller EE, Mayr JA, Zimmermann FA, Feichtinger RG, Stanger $O$ et al. (2012) Reduction of nuclear encoded enzymes of mitochondrial energy metabolism in cells devoid of mitochondrial DNA. Biochem Biophys Res Commun 417: 1052-1057. doi:10.1016/j.bbrc. 2011.12.093. PubMed: 22222373 
41. Mercy L, Pauw Ad, Payen L, Tejerina S, Houbion A et al. (2005) Mitochondrial biogenesis in mtDNA-depleted cells involves a $\mathrm{Ca2+-}$ dependent pathway and a reduced mitochondrial protein import. FEBS J 272: 5031-5055. doi:10.1111/j.1742-4658.2005.04913.x. PubMed: 16176275.

42. Wojtovich AP, Smith CO, Haynes CM, Nehrke KW, Brookes PS (2013) Physiological consequences of complex II inhibition for aging, disease, and the mKATP channel. Biochim Biophys Acta 1827: 598-611. doi: 10.1016/j.bbabio.2012.12.007. PubMed: 23291191.

43. Wojtovich AP, Nehrke KW, Brookes PS (2010) The mitochondrial complex II and ATP-sensitive potassium channel interaction: quantitation of the channel in heart mitochondria. Acta Biochim Pol 57: 431-434. PubMed: 21103454.

44. Carrozzo R, Wittig I, Santorelli FM, Bertini E, Hofmann S et al. (2006) Subcomplexes of human ATP synthase mark mitochondrial biosynthesis disorders. Ann Neurol 59: 265-275. doi:10.1002/ana. 20729. PubMed: 16365880.

45. Buchet K, Godinot C (1998) Functional F1-ATPase essential in maintaining growth and membrane potential of human mitochondrial
DNA-depleted rho degrees cells. J Biol Chem 273: 22983-22989. doi: 10.1074/jbc.273.36.22983. PubMed: 9722521.

46. García JJ, Ogilvie I, Robinson BH, Capaldi RA (2000) Structure, functioning, and assembly of the ATP synthase in cells from patients with the T8993G mitochondrial DNA mutation. Comparison with the enzyme in Rho( 0$)$ cells completely lacking mtdna. J Biol Chem 275: 11075-11081. doi:10.1074/jbc.275.15.11075. PubMed: 10753912.

47. Robinson JB Jr, Inman L, Sumegi B, Srere PA (1987) Further characterization of the Krebs tricarboxylic acid cycle metabolon. J Biol Chem 262: 1786-1790. PubMed: 2433288.

48. Haggie PM, Verkman AS (2002) Diffusion of tricarboxylic acid cycle enzymes in the mitochondrial matrix in vivo. Evidence for restricted mobility of a multienzyme complex. J Biol Chem 277: 40782-40788. doi:10.1074/jbc.M207456200. PubMed: 12198136

49. Gebert N, Gebert M, Oeljeklaus S, von der Malsburg K, Stroud DA et al. (2011) Dual function of Sdh3 in the respiratory chain and TIM22 protein translocase of the mitochondrial inner membrane. Mol Cell 44: 811-818. doi:10.1016/j.molcel.2011.09.025. PubMed: 22152483. 